\title{
REFLECTIVE EQUILIBRIUM AND NORMATIVE RECONSTRUCTION: RECASTING THE PHENOMENOLOGICAL DEFICIT OF CRITICAL THEORY
}

\author{
EQUILÍBRIO REFLEXIVO E RECONSTRUÇÃO NORMATIVA: \\ REFORMULANDO O DÉFICIT NEUROFENOMENOLÓGICO DA TEORIA \\ CRÍTICA
}

NYTHAMAR DE OLIVEIRA ${ }^{1}$

(PUCRS, Brazil)

\begin{abstract}
In this paper, which reflects an ongoing interdisciplinary research in Cognitive and Social Sciences, I recast the normative claims of a political constructivism in reflective equilibrium (Rawls) and of a formal, pragmatic reconstruction (Habermas) as instances of a weak social constructionism. I proceed thus to investigate how social, evolutionary processes, in both semantic and normative terms (Brandom), may be said to pursue universalizable, valid normative claims that could be justified from an externalist standpoint, generated through reflective equilibrium without reductionism.

Keywords: Rawls. Habermas. Political constructivism. Reflective equilibrium.
\end{abstract}

1. In an ongoing research, I have tried to investigate in what sense social, political constructivism (Rawls) and formal, pragmatic reconstruction (Habermas) may be taken as defensible instances of a weak or mitigated methodological social constructionism to the extent that both preserves the idea of objectivity and that is articulated in terms of cognitive moral normativity. By exploring the Rawlsian idea of "reflective equilibrium" and Habermas's program of "normative reconstruction, I have been arguing for naturalism and cultural relativism without giving up on a conception of normativity, albeit not absolutist, with the help of new interfaces that can encompass the differences between mitigated conceptions of naturalism and normative, empirical takes on culture. (Oliveira, 2011; 2012c; 2013) In the final analysis, the problem of striking a balance between mitigated conceptions of naturalism, normativity, and social constructionism helps to consolidate a sustainable view of neuroethics that refers back to the practical-theoretical articulation of ontology, language, and subjectivity. From a strictly ontological perspective, nature has to do with all real things that exist, inorganic, organic, and living beings that can be investigated by -to employ Husserl's terminology- 
"regional ontologies" such as physics, chemistry, biology and natural sciences overall -given the parts-whole problems in formal ontology and logic. (Smith, 1982) Thus, natural ontology deals with real, natural beings, what things are and how they come into being, become, evolve and cease to be. Hence, ontology deals grosso modo with being and beings as they exist, necessarily, possibly or contingently, very much as traditionally and broadly conceived, as the study of what there is. In analytic philosophy, the ontological dimension has been aptly evoked to call into question essentialist, culturalist, and historicist definitions of nature and naturalism, as "methodological (or scientific) naturalism" assumes that hypotheses are to be explained and tested only by reference to natural causes and events. Thus Willard Quine's "naturalized epistemology" and metaphysical naturalism (or ontological naturalism) refer us back to the question "what does exist and what does not exist?" as the very existence of things, facts, properties, and beings is what ultimately determines the nature of things. In the continental camp, Quentin Meillassoux (2006) has articulated a radical critique of correlationism, which has dominated post-Kantian antirealism from German idealism through phenomenological and hermeneutical interpretations of reality and nature (esp. Hegel, Husserl, Heidegger, Sartre, Merleau-Ponty, Foucault, Derrida), as well as in contemporary analytical critics of realism (esp. Putnam, Davidson, Blackburn). Accordingly, correlationism holds that one cannot know reality as it is objectively or in itself, but only insofar as it is posited for a (transcendental) subject, pro nobis ("for us," as in the Lutheran formulation), as a correlate of consciousness, thought, representation, language, culture or any conceptual scheme. To be sure, Meillassoux's critique of antirealism fails to account for causation, chance, and necessity in natural phenomena, as his mathematical-ontological presuppositions remain in need of justification, although claiming to wholly abandon the principle of sufficient reason. In other words, it is not enough to assume that things are just like mathematical objects are accounted for (say, in set theory), without relapsing into some form of correlational circle. In effect, it seems that both language (as it was assumed in the very beginnings of analytic philosophy) and subjectivity (as it has been the case with continental philosophy since Kant) remain bound up with any tentative account of ontology. To my mind, this is precisely what makes the Husserlian semantic correlation (Bedeutungskorrelation), in light of Husserl's intuitive noematic-noetic differentiation between Gegenstand and Objekt, so important for a better grasp of the conception of Lebenswelt, avoiding thus a post-Hegelian historicized correlation of alterity (being-other) and objectification (being 
its other) of Geist vis-à-vis Natur or the natural becoming of beings overall. As I have tried to show elsewhere, both Habermas and Honneth sought to go beyond the noetic-noematic correlation inherent in Heidegger's takes on reification and formal indication, precisely to rescue the normative grounds of sociality that were missing in the latter.(Oliveira, 2012a, 2012b) I sought then to explore such a semantic correlation in social and political philosophy, as social, political ontology inevitably refers back to subjectivity (moral or social agency, hence intersubjectivity) and language (articulation of meaning, social grammar, language games, shared beliefs and practices). Following Foucault, Apel, and Habermas, three paradigm shifts of ontology, subjectivity, and language (e.g. in natural law, positive rights, and legal hermeneutics, respectively), can be shown to be co-constitutive and interdependent, insofar as they account for the problem of the social reproduction of the modern, rationalized lifeworld through the differentiated models of a sociological descriptive phenomenology, of a hermeneutics of subjectivation, and of a formal-pragmatic discourse theory. Just as a Kantianinspired "transcendental semantics" accounts for the articulation of meaning ("Sinn und Bedeutung," in Kant's own terms) in the sensification (Versinnlichung) of concepts and ideas as they either refer us back to intuitions in their givenness (Gegebenheit) of sense or are said to be "realizable" (realisierbar) as an objective reality (since ideas and ideals refer, of course, to no sensible intuition), a formal-pragmatic correlation recasts, by analogy, the phenomenologicalhermeneutical signifying correlation (Bedeutungskorrelation) between ontology, subjectivity, and language without presupposing any transcendental signified, ontological dualism (Zweiweltenthese), or fundamental relationship between subject and object, theory and praxis. And yet the very irreducibility of the hermeneutic circle, together with the incompleteness of its reductions inherent in such a systemic-lifeworldly correlation, seems to betray a quasitranscendental, perspectival network of signfiers and language games. Habermas's wager is that his reconstructive communicative paradigm succeeds in overcoming the transcendental-empirical aporias and avoids the pitfalls of a naturalist objectivism and a normativist subjectivism through a "linguistically generated intersubjectivity." (Habermas, 1987, 297) It would be certainly misleading and awkward to oppose "ontology" to "language" and "subjectivity" as if these were "regional" ontologies or mere subfields of the former. Both Husserlian and Quinean models face meta-ontological problems that remain as unaccounted for as their ontological commitments and axiomatic presuppositions. (Hofweber, 2013)

ethic@ - Florianópolis v.13,n.1, p. 91 -111,Jun. 2014. 
2. Since August 2012, I have been committed to pursuing interdisciplinary research in the philosophy of neuroscience, neuroethics, and social neurophilosophy, especially focusing on the relation between naturalism and normativity, so as to avoid the reduction of either to the other, by stressing the inevitability of bringing in the two other poles of the semantic correlation whenever dealing with ontology, language, and subjectivity. As Prinz's takes on transformation naturalism and concept empiricism allow for an interesting rapprochement between social epistemology and critical theory, his critical views of both naturism (i.e., reducing the naturenurture pickle to the former's standpoint) and nurturism (conversely reducing it to the latter) not only successfully avoid the extremes and reductionisms of (cognitivist) rationalism and (noncognitivist) culturalism -such as logical positivism and postmodernism-, but turns out to offer a better, more defensible account of social epistemic features and social pathologies than most social epistemologists (Goldman et al.) and critical theorists (Habermas, Honneth et al.) have achieved thus far.(Prinz, 2012, 840-842) After all, one cannot speak of naturalist normativity or normative naturalism without a certain embarrassment. And yet, as over against traditional conceptions that regard naturalism as merely descriptive, as opposed to prescriptive accounts of normativity, it has become more and more common nowadays to challenge such a clear-cut division of labor, as naturalists like Millikan (1989) assign normative force to the biological concept of function and normativists like Korsgaard tend to assume that human psychology is naturally normative: "whatever confers a normative status on our actions whatever makes them right or wrong - must also be what motivates us to do or avoid them accordingly, without any intervening mechanism." (Korsgaard, 2010,16) To be sure, both views could be regarded as simply recasting the externalist-internalist debate over the problems of teleology, intentionality, motivation and carrying out an action supposed to be moral. Still, inflationary and deflationary views of both naturalism and normativity are to be contrasted with stricter, conservative views, such as the ones espoused by Derek Parfit's non-naturalist cognitivism and correlated irreducibly normative truths: "Words, concepts, and claims may be either normative or naturalistic. Some fact is natural if such facts are investigated by people who are working in the natural or social sciences. According to Analytical Naturalists, all normative claims can be restated in naturalistic terms, and such claims, when they are true, state natural facts. According to Non-Analytical Naturalists, though some claims are irreducibly normative, such claims, when they are true, state natural facts. According to Non-Naturalist Cognitivists, 
such claims state irreducibly normative facts."(Parfit, 2011, 10) Having been deeply influenced by Davidson's anomalous monism, as Hornsby was, other critics of naturalism and of Quine's Naturalized Epistemology program have argued that one cannot conceive of belief without some appeal to normative epistemic notions such as justification or rationality, assuming that all beliefs are susceptible to being rationally assessed or, in Kantian terms, to being reflexively judged (beurteilen). The upshot of this account is that mental events are not identical to physical events precisely because they are instantiations of mental properties, but are realized by them. Jaeguon Kim (2004) goes as far as to argue that "the concept of belief is an essentially normative one" so as to inflate normative claims in beliefs and especially within a certain conception of epistemic normativity. We can realize that classical epistemology has come under attack on two fronts, namely, in naturalist criticisms raised against a priori assumptions and in normative claims that led to the emergence of social epistemology, as the collective dimension of cognitive processes and interpersonal relations - already anticipated by Habermas's discourse ethicscould provide conditions for normative justification within a given community or social lifeworld, so as to accommodate naturalist inputs for social evolution. Furthermore, Habermas's theoretical and practical approaches to normativity and objectivity are subtly combined within a research program of Kantian pragmatism that remains somehow susceptible to dualist interpretations. All in all, Habermas's weak naturalism holds that nature and culture are continuous with one another, hence an upshot of his conception of social evolution is that societies evolve to a higher level only when learning occurs with respect to their normative structures. According to Habermas, "in questions of epistemic validity the consensus of a given linguistic community does not have the last word. As far as the truth of statements is concerned, every individual has to clarify the matter for himself in the knowledge that everyone can make mistakes.”(Habermas, 2003, p. 142) Accordingly, epistemic agreement or disagreement among peers does not solve the problem as in traditional, correspondence theories of truth: in Quinean terms, all beliefs and intuitions can be constantly revised in light of empirical findings, evidence, and observation. As opposed to scientist, positivist dogmas, mitigated versions of naturalism meet halfway - to paraphrase Habermas - with mitigated conceptions of normativity in weak social constructivism, insofar as social evolutionary processes are guided by normative claims, in both reflexive and social terms, with a view to realizing universalizable, valid claims that are justified from the normative standpoint precisely because they are fit for the survival and

ethic@-Florianópolis v.13, n.1,p.91-111, Jun. 2014. 
preservation of the species. I have thus proposed that Habermas's pragmatism could embrace Prinz's transformation naturalism ("a view about how we change our views") and its cultural relativism without adopting moral relativism as long as the universalist, moral premises of its formal pragmatics are ultimately understood as part of ethical learning processes. Habermas (and Honneth, for that matter) never ceased to stress a certain commitment to moral realism, but the pragmatist turn adopted by discourse ethics and critical theory (as well as in Honneth's theory of recognition) embrace a mitigated version inherent in their normative, reconstructive approaches to history, materialism, and human social psychology. We can then make a case for a neuroscientific and neurophilosophical research program that revisits Quinean naturalism, just like Churchland and Putnam did, and goes further in a mitigated version like the ones independently espoused by Searle, Damasio, and Prinz, as they respond to the phenomenological, normative challenges (esp. when dealing with intentionality and consciousness in social life) that avoids trivial conceptions of normativity. Indeed, a programmatic definition of naturalism might trivialize the sense of normativity, as in Jennifer Hornsby's (1997) conception of Naive Naturalism, according to which in order to avoid both physicalist and Cartesian claims about the mind-body problem, we ought to return to common sense and folk psychology as they implicitly endorse normative and first-personish beliefs. The semantic-ontological correlation comes thus full circle vis à vis its networking with language and subjectivity. As Prinz felicitously put it in his neoempiricist, reconstructive theory of emotions: "Moral psychology entails facts about moral ontology, and a sentimental psychology can entail a subjectivist ontology."(Prinz, 2004, 8)

3. Human beings have evolved throughout the times within the complex evolutionary, biological processes that took place on this planet. Social evolution and whichever pertaining moral "progress" are to be understood within psychology and biology, so that their specifically cultural, historical underpinnings should not dissociate intersubjective, subjective and linguistic traits from their ontological milieux. It seems that normativity itself must follow this same kind of correlational rationale, as ethical-moral normativity ultimately fails to be taken for the most fundamental among other forms of normativity -legal, linguistic-semantic, economic, epistemic etc. Unless one assumes from the outset that ethical-moral normativity is prescriptive in a way that radically differs from "weaker" forms of normativity which can be somewhat reduced to descriptive or constative statements. As Prinz put it in Kantian-like terms, "morality is a 
normative domain. It concerns how the world ought to be, not how it is. The investigation of morality seems to require a methodology that differs from the methods used in the sciences. At least, that seems to be the case if the investigator has normative ambitions. If the investigator wants to proscribe, it is not enough to describe." (Prinz, 2004, 1) And Prinz goes on to propose that "descriptive truths about morality bear on the prescriptive," so that "normative ethics can be approached as a social science" and can also - at least to a certain extent — be "fruitfully pursued empirically." (Prinz, 2004, 1f.) This means that moral norms are also social norms, and these emerge out of neurobiological configurations which do not allow for oversimplifying reductionisms. Hence, when a social scientist observes the behavior of, say, Brazilian drivers failing to stop at a STOP sign, she may speculate about different "reasons" why most drivers simply ignore that traffic sign (the intersection is quite slow, there is no cop around, it seems ok to simply slow down and keep going, there is a risk of getting mugged, nobody stops here anyway) - but all forms of rationalization and self-deceptive conditioning fall short of accounting for the legal, moral normativity implicit in the normative expectation that all drivers ought to stop at STOP signs. At any rate, conjectures on reasons for behaving in such and such way are different from a normative account of the meaning of the sign itself, namely, what does "P-A-RE" stand for? Answer: "Stop"! If drivers are supposed to stop (and they know what that sign stands for) why on earth most drivers in this country fail to stop at the STOP sign? To be sure, practical rationality is very tricky precisely because it cannot be merely reduced to a theory (to be put in practice), or at least there is no ethical theory that satisfactorily justifies how people ought to behave or act without taking into account that people actually might fail to do so. In this sense, philosophers have traditionally grouped together ethical-moral, legal-juridical, and socialpolitical norms within the same sub-field of so-called practical rationality, as opposed to theoretical rationality and aesthetic rationality. Authors like Husserl and Habermas tried to conceive of normative grounds in different areas of inquiry or regional ontologies. Besides the trivial division of labor between the observation of actual, social behavior and its empirical underpinnings, on the one hand, and the normative claims and expectations about some idealized, desirable behavior, on the other, we are faced with the Humean-inspired problem of justifying the relationship between the descriptive and prescriptive thrust of both camps. In postHumean terms, saying that there is a normative expectation that water will boil at $100{ }^{\circ} \mathrm{C}$ means for a naturalist that the laws of nature, in given circumstances, allow for such an expectation just 
like effects that are normally observed in a causality-structured universe, in which the boiling point of $\mathrm{H}_{2} \mathrm{O}$ molecules happens to be 100 degrees Celsius or 212 degrees Fahrenheit at sea level etc. Many philosophers, following Popper's post-Humean approach to induction and Frege's concept-use and rules of logical reasoning, would stick to the classical nature-nurture opposition in order to distinguish empirical, natural laws from legal, moral or social norms regarded as conventions, as the latter could be challenged or broken without losing their normative status, while any violation or exception to the former results in a falsification of the law. And yet all these apparently clear-cut distinctions have come under attack in both philosophy of science and theories of normativity -unless of course one is content to start from axioms or presupposed assumptions, even by invoking such hypotheses for the sake of terminology. Now, prior to assuming, like Korsgaard and normativists do, that ethical-moral normativity $\left(\mathrm{N}_{1}\right)$ is to be regarded as the paradigm of the philosophical problem of normativity par excellence, we may try experiencing with different accounts such as legal, economic, epistemic, and semantic.

$\mathrm{N}_{2}$ : (Legal Normativity) Normativity comes down to what we are obligated to do, act or behave in given circumstances. We might think of legal normativity in the binding force and prescriptive dimension of everyday rule-following practices such as the example above of stopping at STOP signs or red lights, following traffic rules or handing a prescription to the pharmacist to buy medicine in a drugstore. Whatever is regarded as prescriptive is said to be normative in a regulative, law-like common sense of anything prescribed in regulatory environments of lifeworldly, everyday practices (taking a medication and attending to traffic signs). This meaning of normative is also socially construed, hence its legal, institutional sense. Already in the beginning of the last century, as they set out to investigate what legitimizes and justifies one's ordinary practice of holding people responsible and its institutional implications in legal codifications, legal theorists such as Kelsen and Hart sought to avoid traditional contractualist and positivist dogmas by viewing Law as a set of procedural standards imposed by the State and governmental, administrative institutions, through rules, basic principles, and laws. According to Hart, Law can only be justified in the practical-normative terms that define the institutional arrangements themselves and the sources of obligations, duties, rights, privileges, and responsibilities of social relations in a constitutional State.(Hart, 1994) By rejecting the traditional conception of law as divine or as absolute commandment to legitimize coercion, Hart offered a sociological critique of traditional conceptions of legal normativity, such as they had been already advanced by Kelsen and Austin. Whether legal and political conceptions of 
legitimacy, sovereignty and authority come down to secularized theological concepts or not, legal normativity quite naturally exerts its prescriptive, social function of binding force that demands respect and obligation of applicable laws. Certainly, the problem of "normativism" (namely, that rules always refer us to other more basic norms) had been introduced by Kelsen much earlier as he made the intriguing remark that Law can be taken both in a descriptive sense (positive norms, for example, in different legal codifications of the constitution and legislation) and in a prescriptive sense, which ideally would inevitably take us back to a primordial, basic norm (Grundnorm), focusing solely on the formal aspect of rule-following. (Kelsen, 2009)

$\mathrm{N}_{3}$ : (Economic Normativity) Value judgments (normative judgments) can be particularly articulated in terms of economic fairness, what the economy ought to be like or what goals of public policy ought to be. As Amartya Sen pointed out, speaking of economic behavior and moral sentiments, "the impoverishment of welfare economics related to its distancing from ethics affects both welfare economics (narrowing its reach and relevance) and predictive economics (weakening its behavioral foundations).'(Sen, 1998, 28) Commenting on this text, Hilary Putnam -who shares in with Habermas that sameness of reference turns out to be a formal pragmatic presupposition of communication (Habermas sought, must be said en passant, to repair the misleading reception of a discursive or consensus theory of truth, but remains unconvinced about Putnam's critique of Kant's deontological view of normativity, as opposed to objectivity in the natural sciences) - remarks that judgments of reasonableness can be objective and they have all of the typical properties of value judgments so that "knowledge of facts presupposes knowledge of values." (Putnam, 2002, 134) Putnam is ultimately seeking to blur the division of labor between naturalism and normativity by pointing to this tricky ambiguity in economic normativity, as economic values can be as descriptive as prescriptive.

$\mathrm{N}_{4}$ : (Epistemic Normativity) Epistemic normativity is "a status by having which a true belief constitutes knowledge." According to Sosa, epistemic normativity is "a kind of normative status that a belief attains independently of pragmatic concerns such as those of the athlete or hospital patient." Hence, we "must distinguish the normative status of knowledge as knowledge from the normative status that a bit of knowledge may have by being useful, or deeply explanatory, and so on.”(Sosa, 2010, 27) From epistemic normativity we may as well infer that epistemic logic, as it has been proposed by Alchourron and Bulygin, explores the possibility of a logic of norms, which is to be distinguished from the logic of normative propositions. Roughly,

ethic@-Florianópolis v.13,n.1,p.91-111,Jun. 2014. 
the distinction is that the former are prescriptive whereas the latter are descriptive. In the second sense, the sentence "it is obligatory to keep right on the streets" is a description of the fact that a certain normative system (say, of social norms) contains an obligation to keep right on the streets. In the first sense, this statement is the obligation of traffic law itself. (Alchourron and Bulygin, 1981, 179)

$\mathrm{N}_{5}$ : (Linguistic Normativity) "Normative" in a linguistic, semantic sense pertains to the binding sense of patterns or standards of grammar (linguistics) or meaning (semantics and pragmatics), inevitably allowing for a structural opposition between what is (said, written, displayed in a sign) and what ought to be effectively inferred, understood, meant or constructed as an acceptable meaningful word, phrase, sentence or expression. Both Husserl and Quine provided us with some of the first insights into a theory of meaning intertwined with semantic, linguistic normativity. When dealing with "phonetic rules" in his seminal text against the logicalpositivists' normative epistemology, Quine inaugurated a naturalist program that does justice to what actually happens when we use words to refer to states of affairs. So when someone utters the word "red," there is a linguistic-semantic normativity that allows, in everyday practices of conversation and communication, a certain determination of the intended meaning, despite indeterminacies or variations of what is sensuously perceived, spoken and heard in terms of pronunciation, accent or sounds, regardless of analyticity and meaning.(1960, p. 85) Both Habermas and Robert Brandom conceive of inferences as social practices, as they embrace pragmatism as a third way between the empiricist, objectivist linguistic turn of analytic philosophy and the phenomenological, hermeneutic turn of continental philosophy. According to Habermas, "the most salient and striking difference between the hermeneutic and the analytic tradition" is that the latter does not engage in cultural critique vis à vis "looser and larger issues of a diagnostics of an era."(Habermas, 2007, 79) In the opening paragraph of the third chapter, Habermas goes on to assert that "Brandom's Making It Explicit is a milestone in theoretical philosophy just as Rawls's A Theory of Justice was a milestone in practical philosophy in the early 1970s."(2007, 131) To make a very long story short, Habermas and Brandom succeeded in renewing the theory-praxis problematic that was recast by Kant's semantic turn, and the contemporary analytic and continental approaches to the linguistic turn, especially by revisiting traditional understandings of practical normativity as giving reasons for acting. In Brandom's case, "inferring is to be distinguished as a certain kind of move in the game of giving and asking 
for reasons" (Brandom, 1994, 157). Brandom's normative, inferentialist pragmatism is evoked here just to signal the holistic attempt to take seriously the late Wittgenstein's contention that the meaning of an expression is its use and furthermore this meaning is fixed by how it is used in inferences, in contrast with regulist, intellectualist rule-following (Brandom, 1994, 15-23) As opposed to sentience - which we humans share with nonverbal animals - , our linguistic, sapience capacities allow us to reflexively master "proprieties of theoretical and practical inference" so as to "identify ourselves as rational" and ultimately effect a "complete and explicit interpretive equilibrium exhibited by a community whose members adopt the explicit discursive stance toward one another [as] social self-consciousness." (Brandom, 1994, 643) As the most important representative of Conceptual Role Semantics, Brandom is regarded, like Habermas, as a meaning normativist, as opposed to naturalists (like Block, Harman and Horwich), insofar as "norms do not merely follow from but are rather determinative of its meaning."(Whiting, 2009) Like Habermas's normative reconstructive appropriation of speech acts theories, Brandom's pragmatist inferentialism set out to reconstruct "the way implicit scorekeeping attitudes of attribution of performances and statuses [that] can be made explicit as ascriptions." (Brandom, 1994, 543, 643) As over against Platonism, Brandom defines pragmatism as the view that discursive intentionality (sapience) is a species of practical intentionality: "that knowing-that (things are thus-and-so) is a kind of knowing-how (to do something)." (Brandom, 135f.) According to Brandom, "One way of putting together a social normative pragmatics and an inferential semantics for discursive intentionality is to think of linguistic practices in terms of deontic scorekeeping. Normative statuses show up as social statuses.” (Brandom, 183f.) According to inferentialism, rule-following must adopt a normative attitude that transcends the individual, psychological or subjective mental states, in that it takes into account all social, institutional dimensions of her own language and community of speakers. This semanticpragmatic meaning was appropriated by Brandom and Habermas, independently, in their respective conceptions of pragmatist inferentialism and formal pragmatics. I myself remain quite convinced that such semantic, pragmatic versions of a normative theory of meaning do address most of the problems raised by the different levels of normativity, especially when combined with an ontological correlate. Even as we go back to normativist claims such as the ones proposed by Korsgaard, as she revisits the later Wittgenstein, on a classic passage:

" 1 . Meaning is a normative notion.

ethic@- Florianópolis v.13,n.1,p.91-111,Jun.2014. 
2. Hence, linguistic meaning presupposes correctness conditions.

3. The correctness conditions must be independent of a particular speaker's utterances.

4. Hence, correctness conditions must be established by the usage conventions of a community of speakers.

5. Hence, a private language is not possible.” (Korsgaard, 1997, p. 136-38)

With Korsgaard, we come full circle in our quest for normative justification, keeping in mind that most moral philosophers and normativists overall assume that ethical-moral normativity $\left(\mathrm{N}_{1}\right)$ must be regarded as the paradigm of the philosophical problem of normativity par excellence. On this view, "moral standards are normative. They do not merely describe a way in which we in fact regulate our conduct. They make claims on us: they command, oblige, recommend, or guide. Or at least, when we invoke them, we make claims on one another. When I say that an action is right I am saying that you ought to do it; when I say that something is good I am recommending it as worthy of your choice."(Korsgaard, 1996, 22) Ethical-moral normativity $\left(\mathrm{N}_{1}\right)$ and theological normativity $\left(\mathrm{N}_{0}\right)$ have been, more often than not, formulated as complementary variants of absolute normativity or of some divine command theory, as if they claimed to provide the "ground zero" for all foundationalist theories. Classical and modern realist theories (esp. Platonic, Neo-Platonic, Thomist and some versions of Aristotelian and Kantian ethical theories) have indeed betrayed some form of theological realism, as attested by different versions of philosophical anthropology and philosophy of history. At the end of the day, however, these "Patterns of Normativity" show the aporetic situation of foundationalist theories of normativity that end up falling back into absolutist dogmas of normativity, such as those of religious principles established by the standpoint of God's eye view, preserving an aporetic stance as a self-defeating hypothesis inevitably obtains:

$\left(\mathrm{N}_{1} \vee \mathrm{N}_{2} \vee \mathrm{N}_{3} \vee \mathrm{N}_{4} \vee \mathrm{N}_{5}\right) \rightarrow \mathrm{N}_{0}$

$\sim \mathrm{N}_{0}$. Hence, $\sim\left(\mathrm{N}_{1} \vee \mathrm{N}_{2} \vee \mathrm{N}_{3} \vee \mathrm{N}_{4} \vee \mathrm{N}_{5}\right)$ [modus tollens]

It would be thus useless to seek to replace $\mathrm{N}_{0}$ with any of the imaginable candidates, say, to assume that ethical normativity or semantic-linguistic normativity is the most fundamental way of establishing the normative force of rationality. It seems equally aporetic to replace $\mathrm{N}_{0}$ with any idea of nature or any imaginable form of "natural" normativity. On the other hand, it seems plausible that, as Rawlsian reflective equilibrium and subsequent accounts of the biological, social evolution of game-theoretic equilibria and fairness norms have shown, an 
antifoundationalist, coherence theory of normativity can be fairly combined with naturalized versions of ethics, law, language, epistemology, economics etc. By recasting a weak social constructionist correlate to a mitigated naturalism, it is reasonable to recognize that, although socially constructed, moral values, practices, devices and institutions such as family, money, society and government cannot be reduced to physical or natural properties but cannot function or make sense without them.

4. In conclusion, we may recall that moral decisions, broadly conceived, can be defined as those to be sorted by rational agents, that is, according to the most reasonable criteria for such persons, under certain conditions (to be more useful, more efficient, leading to the best way of life or simply out of duty as some kind of categorical imperative). Certainly, there is no agreement among philosophers as to what would be "good" or "better", even as to what we call "moral intuitions", which could be constantly subjected to a "reflective equilibrium", in that judgments and intuitions can be revised. Thus, a major challenge to normative theory in ethics, law, and politics nowadays is to articulate a justification that meets rational criteria, both in ontological-semantic and pragmatic terms, taking into account not only issues of reasoning but also interpretation, self-understanding, historicity and language features inherent in a social ethos. In phenomenological or hermeneutic terms, it is said that normativity must be historically and linguistically situated in a concrete context of meaning, inevitably bound to constraints, prejudices and one or more communitarian traditions, receptions and interpretations of traditions. The ongoing dialogues between neurosciences and different traditions of moral philosophy allow thus for a greater rapprochement between analytical and so-called continental philosophy (esp. phenomenology and hermeneutics). Now it is against such a broad, normative background that we have outlined our quest for "patterns of normativity." Moral, ethical, and legal questions relating to normative justification find some of their best practical test in their applicability in social, political philosophy. As Pettit aptly pointed out, contemporary analytical political philosophy has been caught up in a naturalist-normative cul de sac, following the logical positivist dismissal of metaphysics and noncognitivist criticisms of value theories. On the one hand, "since there are few a priori truths on offer in the political arena, its only task in politics can be to explicate the feelings or emotions we are disposed to express in our normative political judgments." On the other hand, there remains the question of "how unquestioned values like liberty and equality should be weighted against each other." (Pettit, 2007, 8f.) Although most

ethic@ - Florianópolis v.13, n.1, p. 91 -111, Jun. 2014. 
analytical thinkers saw that question as "theoretically irresoluble," the publication of John Rawls's A Theory of Justice in 1971 inaugurated a renewed interest in reconciling a priori claims that "may be relatively costly to revise" with the dense, changing flow of human experience, reminiscent of the practical-theoretical bridging pursued by the normative, emancipatory claims of Critical Theory, beyond positivist and instrumentalist approaches to social reality. In effect, Rawls conceived of an original position (ideal theory) as an attempt to model the considerations that determine the principles of justice for a well-ordered society, in which public criteria for judging the feasible, basic structure of society would be publicly recognized and accepted by all (nonideal theory). Hence the procedural device of rules or public criteria which parties in the original position would endorse prudentially is to be constructed from behind a veil of ignorance, so that the parties know nothing specific about the particular persons they are supposed to represent. Beyond the essentialist views of natural law and contractualist traditions, Rawls's normative conception of the person accounted for the ingenious strategy of resorting to a reflective equilibrium, conceived as a procedural device between a nonideal theory (where we find ourselves, citizens with considered judgments or common sense intuitions) and an ideal theory, in which a public conception of justice refers to free and equal persons with two moral powers (sense of justice and conception of the good). Reflective equilibrium belongs thus together with the original position and the well-ordered society, so as to carry out the thoughtexperiment of an ideal theory of justice which ultimately meets nonideal needs and capacities. To be sure, Rawls's original conception of "justice as fairness," following the Dewey Lectures, was recast into a "political liberalism" which resorted to a wide reflective equilibrium as a constructivist methodology of substantive justification, whose goal was certainly not to account for metaethical problems inherent in the ideas of justice and equal liberty, but to justify specific principles as a reasonable basis for public agreement in particular areas of social life. Baynes (2013, 489f.) has shown that Habermas's program of "normative reconstruction" in political philosophy explicitly refers to the Rawlsian idea of reflective equilibrium and his procedural conception for two reasons: "First, he [Habermas] claims that the fundamental ideal that forms the 'dogmatic core' of his theory is not itself simply one value among others, but reflects a basic norm implicit in the very idea of communicative action. Second, he claims that this ideal can in turn be used to describe a set of (ideal) democratic procedures. It is because the procedures sufficiently mirror this basic ideal, however, that we are entitled to confer a presumption of 
reasonableness or fairness upon them." According to Habermas, the normative grounds for reconstruction are implicit practices or cognitive schemas -and not unconscious experiences to be revealed by a reflective method (like psychoanalysis) - , whose reconstruction refers back to system-based rules as a general reference for all subjects in the process of identity formation and whose intuitive systems of knowledge and competencies depend on previous reconstructions (in empirical sciences like linguistics and cognitive psychology). It has been argued that John Dewey's conception of reconstruction in moral and political philosophy (Dewey, 2004), as it has been critically appropriated by Rawls, Habermas, and Honneth, not only serves to account for the affinities between reflective equilibrium and normative reconstruction among pragmatists, but may also be brought in with a view to better understanding why proceduralist versions of political constructivism remain a reasonable response to the ongoing challenges of cultural relativism and ever-changing pluralist, globalized societies (Benhabib 1986, 1992). Insofar as they both preserve the idea of objectivity in terms of a cognitivist view of moral normativity without falling back into intuitionist realism and reductionist versions of naturalism, I argue that nature and culture are continuous with one another, hence an upshot of such a reconstructive conception of social evolution is that societies evolve to a higher level only when learning occurs with respect to their normative structures. Weak naturalism allows thus for social evolutionary processes guided by normative claims, in both reflexive and social terms, with a view to realizing universalizable, normative claims that are justified from the moral standpoint, always generated through reflective equilibrium, broadly conceived, and naturalized in a democratic ethos in the making. Like Rawls and Habermas, Benhabib and Honneth also resort to reflexive, reconstructive conceptions of critical theory, but by radicalizing the pragmatist turn vis à vis first and second generations of the Frankfurt School, they also succeed in unveiling thick-thin problematizations within the very sought-after normativity in social, concrete experiences of freedom, recognition, and claims of cultural, political identities. Normative claims in cultural identities share in the same justificatory difficulty that can be found in other claims, say, theoretical, if we are to avoid any facile resort to religious dogma or reductionist naturalism. Normative reconstruction has also been appropriated by Honneth to comprise the reconstruction of the legal and moral legitimacy of liberal, democratic institutions. Normative reconstruction comes down to an in-depth analysis of the social reality of liberal democracies, as their institutionalized conditions of normativity come under scrutiny. Some of these premises are to be

ethic@-Florianópolis v.13, n.1, p. 91-111, Jun. 2014. 
found in Habermas's insights into the social evolution and the social reproduction of a society as determined by their shared universal values, in a post-traditional conception of Sittlichkeit. As opposed to the scientific models of reflective criticism (like psychoanalysis), Habermas thought of logic, linguistics, moral and cognitive psychology as reconstructive sciences whose practical activities implicitly set rules and regulations that were basic to ongoing practices of everyday activities, such as reasoning, speaking, and feeling. Linguistic systems are thus conceived as rules, accordingly, as necessary preconditions that enable rational discussion and can be made explicit upon reflection. The most important features of such a "reconstructive science" lie in their comparison with the "critical sciences," as Habermas outlines three of their distinguishing aspects: (1) the foundations of reconstruction are implicit practices or cognitive schemas, and not unconscious experiences revealing the pseudo-objectivity of a reflective method; (2) the reconstruction regards the anonymous system-based rules as a general reference for all subjects and not as individual and particular subjects in the process of identity formation; (3) the explicit reconstruction of intuitive systems of knowledge and competencies has no practical consequences, while reflection seeks to make conscious the unconscious structures in order to escape false consciousness.(Habermas, 1971; 1979, p. 130-177; Voirol, 2012)

According to Benhabib (1994), one might recall the immanent critique of existing legal and social arrangements, the reconstructive imagination of different ethical values, relationships and institutions, and the design of political strategies which seek to change current legalinstitutional arrangements as integrating the same pragmatist research program in critical theory, leading all the way to the critical, immanent reconstruction of Honneth's normative reactualization of an intersubjective, Hegelian-inspired anthropology of recognition, as selfrealization and self-determination can only be realized and fulfilled in intersubjective, relational experiences of social life, the locus par excellence of normative expectations (sociality being ultimately the basis of both individual well-being and suffering). This is a subtle, radical shift away from a propositional understanding of language and semantics, for instance, even when one asserts that "it ought not to be the case that $\mathrm{p}$ and not-p" (say, to exemplify the principle of noncontradiction or that contradictory statements cannot both be true in the same sense at the same time), there is a certain "normative surplus of practice" as the assertion could be taken in an ontological, a psychological or a semantic sense - or all of them-, as pointed out by Ernst Tugendhat (1986), and in favor of both Habermas's and Brandom's takes on semantic 
externalism. After all, intentional content does depend on how the world is objectively and firstpersonish accounts may (be complemented by and) give way to third-person stances (as in Brandom's pragmatic, inferentialist approach): "Norms come into the story at three different places: the commitments and entitlements community members are taken to be attributing to each other; the implicit practical proprieties of scorekeeping with attitudes, which institute those deontic statuses; and the issue of when it is appropriate or correct to interpret a community as exhibiting original intentionality, by attributing particular discursive practices of scorekeeping and attributing deontic statuses. It is normative stances all the way down."(Brandom, 1994, 637f.)

And yet, as Habermas would point out, normative pragmatics must be compatible with nonreductive, weak naturalism (and materialism), as long as the social, public dimension of consent or agreement can be shown to be decisive for moral normativity in a conventional or nonnatural sense. For this reason, Habermas thinks that Brandom overlooks the intersubjective interpretation of objective validity and proposes thus to identify the normative thrust of epistemic and moral beliefs with validity claims. What I have dubbed "the phenomenological deficit of critical theory" (das phänomenologische Defizit der Kritischen Theorie), inherent in the Frankfurt School's attempt at a dialectic of enlightenment that breaks away from the demonization of the technological, instrumental domination of nature, consists thus in recasting an immanent, reconstructive critique of society with a view to unveiling lifeworldly practices that resist systemic domination, without reducing the former to self-referential stances of normativity or the latter to reified, naturalist machineries of social control. If the problematic relationship between systems and lifeworld lies at the bottom of the normative grounds of social criticism, a self-understanding of our modern condition turns out to be an interesting instance of a normative reconstruction of systemic-lifeworldly technologies that resist reifying normalization as they contribute to accounting for meaning through a linguistically generated intersubjectivity. 
Notes:

1 Pontifícia Universidade Católica (PUCRS), Porto Alegre, Rio Grande do Sul, Brazil. E-mail: nythamardeoliveira@gmail.com

ethic@- Florianópolis v.13,n.1,p.91-111,Jun. 2014. 


\section{References}

Alchourron, Carlos and Eugenio Bulygin, 1981. "The expressive conception of norms." In: Risto Hilpinen, ed. New Studies in Deontic Logic: Norms, Actions, and the Foundations of Ethics. Dordrecht: Reidel.

Baynes, Kenneth. 2013. "Rawls and Critical Theory." In Mandle, Jon and David A. Reidy (editors). Blackwell Companion to Rawls. Oxford: Blackwell.

Benhabib, Seyla. 1986. Critique, Norm and Utopia. A Study of the Foundations of Critical Theory. New York: Columbia University Press.

. 1992. Situating the Self. Gender, Community and Postmodernism in Contemporary Ethics. Polity Press.

Brandom, Robert. 2014. "Intentionality and Language: A Normative, Pragmatist, Inferentialist Approach.” In N. J. Enfield, Paul Kockelman, Jack Sidnell (Editors), The Cambridge Handbook of Linguistic Anthropology. Cambridge University Press.

. 1994. Making it explicit: Reasoning, representing, and discursive commitment. Cambridge: Harvard University Press.

Dewey, John. 2004. Reconstruction in Philosophy. Dover Publications. [1920]

Habermas, Jürgen. 1979. "Toward a Reconstruction of Historical Materialism," in Communication and the Evolution of Society. Trans. Th. McCarthy. Boston: Beacon. [1976] . 1971. Knowledge and Human Interests. Trans. J. J. Shapiro. Boston: Beacon. [1968]

. 1987. The Philosophical Discourse of Modernity. Translated by Frederick Lawrence. Cambridge, MA: MIT Press. [1985] . 2003. Truth and Justification. Trans. B. Fultner. Cambridge, Mass: MIT Press. [1999]

Hart, H. L. A. 1994. The Concept of Law. 2nd edition with Postscript. Oxford: Clarendon Press. [1961]

Hofweber, Thomas. 2013. "Logic and Ontology," The Stanford Encyclopedia of Philosophy (Spring 2013 Edition), Edward N. Zalta (ed.), URL = $<$ http://plato.stanford.edu/archives/spr2013/entries/logic-ontology/>

Hornsby, Jennifer. 1997. Simple Mindedness: In defense of naïve naturalism in the philosophy of mind. Cambridge, MA: Harvard University Press. 
Kelsen, Hans. 2009. Pure Theory of Law. The Lawbook Exchange. [1934]

Kim, Jaegwon. 2004. "What is 'Naturalized Epistemology'?" In E. Sosa and J. Kim (eds.), Epistemology: An Anthology. Malden, Mass.: Blackwell Publishing. p. 301-313.

Korsgaard, Christine M. 2010. "Reflections on the Evolution of Morality." The Amherst Lecture in Philosophy 5 (2010): 1-29. <http://www.amherstlecture.org/korsgaard2010/>.

. 1997. "The Normativity of Instrumental Reason." In Garrett Cullity and Berys Gaut (eds.) Ethics and Practical Reason. Oxford: Clarendon Press, pp. 215-54.

. 1996. The Sources of Normativity. Cambridge: Cambridge University Press.

Meillassoux, Quentin. 2006. Après la finitude: Essai sur la nécessité de la contingence, with a Preface by Alain Badiou. Paris: Seuil.

Oliveira, Nythamar de. 2009. "Habemus Habermas: O universalismo ético entre o naturalismo e a religião", ethic@8/1 (2009):31-50.

. 2011. "Gadamer, a hermenêutica e a crítica ao naturalismo: Antirrealismo moral e construcionismo social," in Ernildo Stein e Lenio Streck (orgs), Hermenêutica e Epistemologia. Porto Alegre: Livraria do Advogado.

.2012a. "Heidegger, Reification and Formal Indication." Comparative and Continental Philosophy Vol. 4, No 1 (2012): 46-65.

.2012b. "The Normative Claims of Brazil's Democratic Ethos: Bourdieu's Habitus,

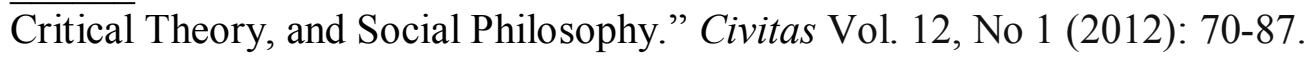

. 2012c. "Breves Observações sobre Normatividade e Naturalismo," in Epistemologia Social. Orgs. Felipe Müller \& Tiegüe Rodrigues. Porto Alegre: Edipucrs. p. 145-161.

. 2013. "Recasting the Naturalism-Normativity Debate: Neuroscience, Neurophilosophy, Neuroethics". Principios Vol. 20 No. 33 (2013): 79-103.

Millikan, Ruth. 1989. "Biosemantics,” Journal of Philosophy 86 (1989): 281-297.

Parfit, Derek. On What Matters, vol. II. Oxford University Press.

Pettit, Philip. 2013. "Analytical Philosophy." In: Goodin, Robert, Philip Pettit and Thomas Pogge (editors), 2007. A Companion to Contemporary Political Philosophy. $2^{\text {nd }}$. Edition. Oxford: Blackwell.

Prinz, Jesse. 2012. Beyond Human Nature: How Culture and Experience Shape Our Lives. Penguin UK Kindle Edition.

ethic@- Florianópolis v.13,n.1,p.91-111,Jun.2014. 
. 2004. The Emotional Construction of Morals. Oxford University Press.

Putnam, Hilary. 2002. The collapse of the fact/value dichotomy and other essays. Harvard University Press.

Quine, Willard V. 1948. “On what there is," Review of Metaphysics, vol. 2 (1948): 21-38. . 1960. Word and Object. Boston: MIT Press.

Sen, Amartya. 1998. On Ethics and Economics. Oxford University Press.

Smith, Barry (ed.). 1982. Parts and Moments: Studies in Logic and Formal Ontology. Munich and Vienna: Philosophia Verlag.

Sosa, Ernest. 2010. Virtue Epistemology. Oxford University Press.

Tugendhat, Ernst, mit Ursula Wolf. 1986. Logisch-Semantische Propädeutik. Reclam, Stuttgart.

Voirol, Olivier. 2012. "Quel est l'avenir de la théorie critique?" Questions de communication 21 (2012): 107-122.

Whiting, Daniel. 2009. "Conceptual Role Semantics," Internet Encyclopedia of Philosophy: $<$ http://www.iep.utm.edu/conc-rol/>

Recebido / Received: 01/05/2014

Aprovado / Approved: 12/06/2014

ethic@ - Florianópolis v.13,n.1,p.91-111,Jun. 2014. 